\title{
Effectiveness of Honey Packaged Against The Testeless Taste of Salmonella typhi Bacteria
}

\author{
Melli Marlina', Bastian² \\ 1,2 Program Studi DIV Teknologi Laboratorium Medis Fakultas Sains dan Teknologi Institut Ilmu Kesehatan dan Teknologi \\ Muhammadiyah Palembang, Indonesia
}

\begin{tabular}{l}
\hline Article Info \\
\hline Article history: \\
Received Aug $10^{\text {th }}, 2021$ \\
Revised Aug $30^{\text {th }}, 2021$ \\
Accepted Sep $01^{\text {st }}, 2021$ \\
\hline
\end{tabular}

Keyword:

Salmonella typhi bacteria, Honey packaged

\begin{abstract}
Typhoid fever or typhus abdominalis is an acute infection that occurs in the small intestine caused by gram negative bacteria Salmonella typhi which is transmitted through food or beverages contaminated by feces or urine from honey is honey made from pure honey of an infected person. Packaged honeychoice that has previous been processed in such a sterile and hygienic way packaged at various sizes and prices that are more affordable than natural honey. With the production of packaged honey that is widespread and affordable prices will make it easier for people to consume honey. This study aims to find out the effectiveness of packaged honey against the tasteless tasete of Salmonella typhi bacteria. This type of research is conducted in the form of pure experimentation that is analyzed in a quantitatively discrete manner and presented in the form of a simple diagram. The research was conducted at the Microbiology Laboratory of the Institute of Health Sciences and Technology of Muhammadiyah Palembang using the method of disc diffusion paper discs. The results of this study obtained average the effectiveness of packaged honey against the tasteless bacteria Salmonella typhi at a concentration of $25 \%$ not formed, $50 \%$ by $2.4 \mathrm{~mm}$ and $75 \%$ by $5.4 \mathrm{~mm}$ with the wilcoxon test obtained a value of $\mathrm{p}=0.006$. The conclusion of this study is that packaged honey with concentrations of $25 \%$, $50 \%$, and $75 \%$ has no effectiveness against the tastelessness of Salmonella typhi bacteria.
\end{abstract}

\section{ABSTRAK}

Demam tifoid atau typhus abdominalis adalah suatu infeksi akut yang terjadi pada usus halus disebabkan oleh bakteri gram negatif Salmonella typhi yang ditransmisikan melalui makanan maupun minuman yang terkontaminasi oleh feses atau urin dari orang terinfeksi. Madu kemasan adalah madu yang dibuat dari madu murni pilihan yang sebelumnya telah diproses sedemikian rupa secara steril dan higienis kemudian dikemas dengan berbagai ukuran dan harga yang lebih terjangkau dari pada madu alami. Penelitian ini bertujuan untuk mengetahui efektivitas madu kemasan terhadap daya hambat bakteri Salmonella typhi. Jenis penelitian ini dilakukan dalam bentuk eksperimen murni yang dianalisa secara diskriptif kuantitatif dan disajikan dalam bentuk diagram sederhana. Penelitian dilakukan di Laboratorium Mikrobiologi Institut Ilmu Kesehatan dan Teknologi Muhammadiyah Palembang dengan menggunakan metode disk difusi cakram kertas. Hasil penelitian ini didapatkan rata - rata efektivitas madu kemasan terhadap daya hambat bakteri Salmonella typhi pada konsentrasi $25 \%$ tidak terbentuk, $50 \%$ sebesar 2,4 mm dan 75\% sebesar 5,4 mm dengan uji wilcoxon didapatkan nilai $p=$ 0,006. Kesimpulan dari penelitian ini yaitu madu kemasan dengan konsentrasi $25 \%, 50 \%$, dan $75 \%$ tidak memiliki efektivitas terhadap daya hambat bakteri Salmonella typhi.

Kata Kunci : Bakteri Salmonella typhi, Madu Kemasan

\section{Pendahuluan}

Demam tifoid atau typhus abdominalis adalah suatu infeksi akut yang terjadi pada usus halus tepatnya di patch of peyer's, disebabkan oleh kuman gram negatif Salmonella typhi yang ditransmisikan melalui makanan maupun minuman yang terkontaminasi oleh feses atau urin dari orang terinfeksi. Salmonella typhi adalah bakteri batang gram negatif yang tidak memiliki spora, bergerak dengan flagel peritrik, bersifat intraseluler fakultatif dan 
anerob fakultatif, ukurannya berkisar antara $0,7-1,5 \times 2-5 \mu \mathrm{m}$. Bakteri ini akan mati pada pemanasan $57^{\circ} \mathrm{C}$ selama beberapa menit, Salmonella typhi mampu bertahan hidup selama beberapa bulan sampai setahun jika melekat dalam tinja, mentega, susu, keju dan air beku. Bakteri Salmonella typhi tahan terhadap selenit dan natrium deoksikolat yang dapat membunuh bakteri enterik lain, menghasilkan endotoksin, protein kinvasin dan MRHA (Mannosa Resistant Haemaglutinin). (Ristiansyah., 2018) Bakteri ini terus mengalami perkembangan dalam sifat resistensi terhadap antibiotik. Bakteri Salmonella typhi yang resisten terhadap beberapa antibiotik yaitu kloramfenikol, kotrimoksazol, tetrasiklin dan ampisilin atau dikenal sebagai Multi Drug Resistent Salmonella typhi (MDRST). Penggunaan obat secara terus menerus seperti kloramfenikol dan tiamfenikol dapat menyebabkan terjadinya penekanan sumsum tulang belakang dan anemia aplastik, serta terganggunya pertumbuhan tulang rawan anak akibat penggunaan golongan fluorokuinolon yaitu siprofloksasin. Berdasarkan hal tersebut, diperlukan alternatif lain seperti penggunaan bahan alam. (Hapsoro., 2018)

Selama terjadi infeksi, bakteri tersebut bermultiplikasi di dalam sel fagosit mononuklear dan berkelanjutan dilepaskan ke aliran darah. Pada sore hingga malam hari demam meningkat secara perlahan yang disertai dengan anoreksia, nyeri abdomen dan sering ditemukan adanya lidah kotor berselaput putih, perdarahan gastrointestinal, perforasi usus yang dapat menimbulkan bahaya bahkan syok ataupun kematian bagi penderita. (Purba., 2019) Gejala penyakit infeksi ini biasanya adalah demam pada sore hari selama satu minggu atau lebih dengan keluhan klinis seperti anoreksia dan nyeri abdomen. Dapat disertai dengan terdapatnya lidah kotor, nyeri tekan perut dan adanya pembengkakan hati atau limpa pada stadium lebih lanjut. Diagnosis demam tifoid adalah bila pasien demam $>38^{\circ} \mathrm{C}$ selama kurang dari 3 hari dengan hasil kultur darah, sumsum tulang yang positif Salmonella typhi. Apabila pada kasus demam tersebut didapatkan hasil positif pada pemeriksaan serologi ataupun deteksi antigen tanpa mengisolasi bakteri. (Marsa., 2020)

Adanya kemajuan teknologi di bidang kesehatan dapat memberikan banyak kemudahan bagi kehidupan manusia selain itu banyak pula dampak negatif yang tidak dapat dihindari seperti meningkatnya kemampuan mempertahankan diri sehingga sulit untuk memberantas mikroba penyebab infeksi melalui penyesuaian, munculnya strain - strain baru yang resisten terhadap antimikroba disebabkan oleh sediaan antimikroba yang tidak rasional mengakibatkan peningkatan kesehatan, angkat kesakitan dan angka kematian. (Winarsih., 2015)

Penatalaksanaan atau pengobatan penyakit infeksi demam tifoid bertujuan untuk mencegah terjadinya komplikasi, menghentikan invasi bakteri, serta memper cepat proses penyembuhan. Pengobatan lain yaitu dengan memberikan obat - obatan untuk mengurangi gejala yang timbul seperti demam dan rasa pusing (paracetamol) sedangkan untuk anak dengan demam tifoid maka pilih antibiotika yang utama seperti klaromfenikol selama 10 hari dan diharapkan terjadi pemberantasan bakteri serta waktu perawatan dipersingkat. Namun beberapa dokter memilih obat antibiotika lain seperti ampicilin, trimethoprin-sulfamethoxazelo, kotrimoksazol, sefalosporin, dan ciprofloxacin sesuai kondisi pasien jika demam yang diderita berlebihan dapat menyebabkan penderita harus dirawat dan diberikan cairan infuse. (Dardi., 2020)

Upaya pengobatan alternatif yang lebih aman dan tidak menimbulkan efek samping seperti pemanfaatan tanaman obat. Sejak zaman dahulu pengobatan tradisional sudah diketahui, disebarkan maupun diwariskan melalui satu orang ke orang lainnya di setiap daerah yang memiliki ciri khas sendiri karena dipengaruhi oleh kondisi alam dan keterbatasan tumbuhan dalam proses pengobatannya, keterbatasan dalam proses pengobatan mengakibatkan banyaknya masyarakat yang memanfaatkan produk alam berupa madu yang dihasilkan oleh lebah karena mengandung nutrisi yang baik. (Ulum., 2017) 
Jurnal Analis Medika Biosains (JAMBS)

Vol.8, No.2, September 2021, pp. 65 - 70

ISSN: 2656-2456 (Online)

ISSN: 2356-4075 (Print)

Madu yang berkualitas harus memberikan manfaat dan memenuhi persyaratan bagi kesehatan. Enzim enzim utama yang terkandung dalam madu yaitu (amilase), invertase (sukrase, a-glukosidase) dan glukosa oksidase yang sangat berperan dalam menguraikan gula - gula sederhana yang terdapat dalam madu itu sendiri berdasarkan SNI 01 - 3545. Pada saat ini madu hasil produksi secara alami oleh lebah dapat mengalami perubahan dari keadaan aslinya seperti adanya aktifitas enzim dalam madu yang kurang baik di tangan manusia dan pada akhirnya akan sampai ke tangan konsumen berupa produksi madu dengan kualitas rendah. Apalagi di zaman sekarang untuk mendapatkan madu dengan kualitas yang tinggi sangatlah sulit karena tingkat produksinya sudah jarang ditemukan dan harga produksi madu lebih mahal oleh karena itu banyak perusahaan - perusahaan yang memproduksi madu kemasan dengan kualitas terjamin, kaya akan vitamin, mineral dan enzim yang sangat bermaafaat bagi tubuh. (Tulandi., 2019)

Madu kemasan adalah madu yang dibuat dari madu murni pilihan yang sebelumnya telah diproses sedemikian rupa secara steril dan higienis kemudian dikemas dengan berbagai ukuran dan harga yang lebih terjangkau dari pada madu alami. Madu kemasan terkadang memiliki warna yang sedikit berbeda meskipun satu varian. Warna yang terdapat pada madu alami tercipta dari beberapa faktor misalnya dari musim bunga yang berlangsung atau tanaman disekitarnya. Hal tersebut dapat mempengaruhi warna madu yang dihasilkan oleh lebah, oleh karena itu warna dari madu kemasan bisa sedikit berbeda begitu pula dengan rasa dari madunya. (Andiyani., 2019)

Mekanisme kerja senyawa flavonoid dalam merusak membran sel bakteri yaitu membentuk senyawa kompleks dengan protein ekstraseluler sehingga membran sel bakteri rusak dan diikuti dengan masuknya air yang tidak terkontrol ke dalam sel bakteri. Hal ini menyebabkan pembengkakan dan akhirnya membran sel bakteri pecah. Selain itu senyawa flavonoid memiliki kemampuan mendenaturasi protein sel bakteri dengan cara membentuk ikatan hidrogen kompleks dengan protein sel bakteri. Sehingga, struktur dinding sel dan membran sitoplasma bakteri yang mengandung protein, menjadi tidak stabil dan kehilangan aktivitas biologinya. Akibatnya fungsi permeabilitas sel bakteri terganggu dan sel bakteri akan mengalami lisis yang berakibat pada kematian sel bakteri. (Putra., 2018)

Penelitian ini bertujuan untuk mengetahui efektivitas madu kemasan terhadap daya hambat bakteri Salmonella typhi, mengetahui konsentrasi efektivitas madu kemasan terhadap daya hambat bakteri Salmonella typhi, dan mengetahui rata - rata efektivitas madu kemasan terhadap daya hambat bakteri Salmonella typhi

\section{Metode Penelitian}

Metode penelitian ini menggunakan Post test - Only Control Design dengan metode disk diffusi cakram kertas untuk melihat efektivitas madu kemasan terhadap daya hambat bakteri Salmonella typhi ATCC 19430. Hipotesis dalam penelitian ini yaitu tidak adanya efektivitas madu kemasan terhadap daya hambat bakteri Salmonella typhi.

Subjek penelitian yang digunakan pada penelitian ini adalah berupa strain murni bakteri Salmonella typhi ATCC 19430 dan madu kemasan yang telah memenuhi kriteria inklusi dan eksklusi (Andayani, 2019). Sampel penelitian menggunakan bakteri Salmonella typhi yang ditanamkan dalam media nutrien agar. Pada penelitian ini, peneliti menggunakan jumlah kelompok perlakuan sebanyak 3 kelompok yaitu madu kemasan dengan variasi konsentrasi $25 \%, 50 \%, 75 \%$. 
Data yang didapatkan dari pemeriksaan laboratorium diolah secara elekronik dengan program SPSS. Tes normalitas menggunakan uji Shapiro - wilk karena jumlah data $<50$. Hasil yang didapatkan dilihat dari sig. yang diperoleh, apabila sig $\geq 0,05$ maka data dinyatakan berdistribusi normal sedangkan apabila sig $<0,05$ maka data dinyatakan tidak berdistribusi normal. (Dahlan., 2013) Bila hasil terdistribusi normal maka dilanjutkan dengan uji Repeated ANOVA. Bila hasil yang didapatkan tidak berdistribusi normal maka dilakukan uji Wilcoxon untuk mengetahui efektivitas madu kemasan terhadap daya hambat bakteri Salmonella typhi.

\section{Hasil Penelitian dan Pembahasan}

Sampel yang digunakan pada penelitian adalah madu kemasan dengan konsentrasi yaitu 25\%, 50\%, dan $75 \%$ dengan kontrol positif (Kloramfenicol) dan kontrol negatif (Aquadest) menggunakan cakram kertas untuk melihat daya hambat bakteri Salmonella typhi.

Tabel 1. Data Hasil Penelitian Efektivitas Madu Kemasan Terhadap Daya Hambat Bakteri Salmonella typhi

\begin{tabular}{cccccc}
\hline Pengulangan & Kontrol + & Kontrol - & \multicolumn{3}{c}{ Konsentrasi Madu Kemasan } \\
\cline { 3 - 5 } & & & $25 \%$ & $50 \%$ & $75 \%$ \\
\hline P1 & $33 \mathrm{~mm}$ & $0 \mathrm{~mm}$ & $0 \mathrm{~mm}$ & $2 \mathrm{~mm}$ & $5 \mathrm{~mm}$ \\
\hline P2 & $33 \mathrm{~mm}$ & $0 \mathrm{~mm}$ & $0 \mathrm{~mm}$ & $3 \mathrm{~mm}$ & $6 \mathrm{~mm}$ \\
\hline P3 & $33 \mathrm{~mm}$ & $0 \mathrm{~mm}$ & $0 \mathrm{~mm}$ & $2 \mathrm{~mm}$ & $5 \mathrm{~mm}$ \\
\hline P4 & $33 \mathrm{~mm}$ & $0 \mathrm{~mm}$ & $0 \mathrm{~mm}$ & $3 \mathrm{~mm}$ & $6 \mathrm{~mm}$ \\
\hline P5 & $33 \mathrm{~mm}$ & $0 \mathrm{~mm}$ & $0 \mathrm{~mm}$ & $2 \mathrm{~mm}$ & $5 \mathrm{~mm}$ \\
\hline P6 & $33 \mathrm{~mm}$ & $0 \mathrm{~mm}$ & $0 \mathrm{~mm}$ & $3 \mathrm{~mm}$ & $6 \mathrm{~mm}$ \\
\hline P7 & $33 \mathrm{~mm}$ & $0 \mathrm{~mm}$ & $0 \mathrm{~mm}$ & $2 \mathrm{~mm}$ & $5 \mathrm{~mm}$ \\
\hline P8 & $33 \mathrm{~mm}$ & $0 \mathrm{~mm}$ & $0 \mathrm{~mm}$ & $3 \mathrm{~mm}$ & $6 \mathrm{~mm}$ \\
\hline P9 & $33 \mathrm{~mm}$ & $0 \mathrm{~mm}$ & $0 \mathrm{~mm}$ & $2 \mathrm{~mm}$ & $5 \mathrm{~mm}$ \\
\hline Rata - Rata & $33 \mathrm{~mm}$ & $0 \mathrm{~mm}$ & $0 \mathrm{~mm}$ & $2,4 \mathrm{~mm}$ & $5,4 \mathrm{~mm}$ \\
\hline
\end{tabular}

Berdasarkan hasil pemeriksaan daya hambat yang terbentuk pada kontrol positif menggunakan (Kloramfenikol) menunjukan adanya efektivitas daya hambat terhadap bakteri Salmonella typhi sebesar $33 \mathrm{~mm}$ sedangkan pada kontrol negatif (Aquadest) tidak terbentuk daya hambat. Menurut Clinical Laboratory Standart Institute (CLSI) 2013 kriteria daya hambat Kloramfenicol yaitu sensitif $\geq 18 \mathrm{~mm}$, intermedate $13-17 \mathrm{~mm}$ dan resisten $\leq 12 \mathrm{~mm}$. Daya hambat terhadap bakteri yang memiliki klasifikasi diameter yaitu kategori lemah dengan diameter $\leq 5 \mathrm{~mm}$, kategori sedang memiliki diameter zona hambat sekitar antara $6-10 \mathrm{~mm}$, dan diameter zona hambat yang kuat sekitar antara 11 - $20 \mathrm{~mm}$. (Susanto., 2012) Rata - rata hasil pemeriksaan daya hambat bakteri Salmonella typhi pada madu kemasan dengan konsentrasi $25 \%$ adalah $0 \mathrm{~mm}$, konsentrasi $50 \%$ adalah $2,4 \mathrm{~mm}$ dan konsentrasi $75 \%$ adalah 5,4 mm yang artinya konsentrasi 75\% lebih tinggi daya hambatnya dari pada konsentrasi $50 \%$ dan 25\% dengan klasifikasi respon hambatan pertumbuhan lemah dengan demikian larutan madu kemasan tidak memiliki efektivitas terhadap daya hambat bakteri Salmonella typhi. Hasil penelitian tersebut harus dilanjutkan dengan analisis menggunakan program SPSS.

Tabel 2. Hasil Uji Wilcoxon 
Jurnal Analis Medika Biosains (JAMBS)

Vol.8, No.2, September 2021, pp. 65 - 70

ISSN: 2656-2456 (Online)

ISSN: 2356-4075 (Print)

Mean Rank Sum of Ranks Asymp. Sig.

\begin{tabular}{lccc|} 
Konsentrasi $75 \%$ Transform & & .00 & .006 \\
- Konsentrasi $50 \%$ & .00 & & \\
\cline { 2 - 4 } Transform & 5.00 & 45.00 & \\
\hline
\end{tabular}

Berdasarkan hasil analisis mendapatkan hasil nilai sig untuk madu kemasan konsentrasi 50\% adalah 0,006 dan madu kemasan dengan konsentrasi $75 \%$ adalah 0.006. Karena nilai sig yang didapat $p<0.05$, berdasarkan hasil tersebut maka dapat di katakan bahwa data pada penelitian terdapat perbedaan konsentrasi pada efektivitas madu kemasan terhadap daya hambat bakteri Salmonella typhi.

Pada penelitian ini mendapatkan efektivitas madu kemasan terhadap daya hambat bakteri Salmonella typhi dengan klasifikasi lemah dikarenakan beberapa faktor yaitu: Pertama, madu kemasan adalah madu yang dibuat dari madu murni yang sebelumnya telah diproses sedemikian rupa dan sudah mengalami pengenceran yang mengakibatkan madu mudah menyebar pada agar bakteri sehingga efek antibakteri menjadi tidak optimal. Kedua, madu kemasan memiliki pH asam sehingga akan menghambat metabolisme bakteri dan menyebabkan bakteri mudah mengalami lisis atau bakteri akan mati. Ketiga, struktur dinding sel bakteri gram negatif lebih tebal dibandingkan bakteri gram positif yang mengakibatkan senyawa antibakteri yang terkandung dalam madu kemasan menjadi sulit masuk kedalam inti sel yang menyebabkan madu kemasan menjadi resisten terhadap bakteri Salmonella typhi.

Efektivitas madu terhadap bakteri multi drug resistent Salmonella typhi dan methicillin resisten Staphylococcus aureus menunjukkan madu pohon kelapa sawit memiliki aktivitas antibakteri terhadap multi drug resistent Salmonella typhi yang membentuk zona hambat pada konsentrasi tertinggi sebesar 11,4 mm pada konsentrasi 90\% dan 13,4 mm pada konsentrasi 100\%. (Rahma., 2018)

Madu alami dan madu kemasan memiliki efektivitas terhadap bakteri Streptococcus beta hemoliticus Group A, dengan diameter daya hambat terbesar dari madu alami yaitu $14 \mathrm{~mm}$ dan madu kemasan didapatkan diameter terbesar yaitu $11 \mathrm{~mm}$. Walaupun demikian, efek antibakteri pada madu kemasan lebih rendah dibandingkan oleh madu alami. (Elsi., 2014)

Aktivitas antibakteri larutan madu hutan terhadap pertumbuhan Escherichia coli dari hasil penelitian menunjukan pada konsentrasi $40 \%$ sampai konsentrasi $100 \%$ terdapat aktivitas antibakteri yang di lihat dari terbentuknya zona bening disekitar disk, sedangkan pada konsentrasi $10 \%$ dan konsentrasi $20 \%$ tidak terdapat aktivitas antibakteri. (Diana., 2019)

\section{Kesimpulan}

Dari hasil penelitian yang sudah dilakukan tentang "Efektivitas Madu Kemasan Terhadap Daya Hambat Bakteri Salmonella typhi" dapat disimpulkan bahwa madu kemasan dengan konsentrasi 25\%, 50\%, dan 75\% tidak adanya efektivitas terhadap daya hambat bakteri Salmonella typhi. Rata - rata efektivitas madu kemasan terhadap daya hambat bakteri Salmonella typhi pada konsentrasi 25\% sebesar $0 \mathrm{~mm}$, konsentrasi 50\% sebesar 2,4 mm dan konsentrasi $75 \%$ sebesar 5,4 $\mathrm{mm}$. 


\section{Daftar Pustaka}

Andayani, Achmad. (2019). Madu TJ Murni: Madu Asli atau Hanya Campuran.

Clinical Laboratory Standart Institute (CLSI). (2013). Performance Standards for Antimicrobial Susceptibility Testing 22th ed. Clinical and Laboratory Standards Institute.

Dahlan M, Sopiyudin. (2013). Statistik Untuk Kedokteran dan Kesehatan: Jakarta.

Dardi Ns Satriana, Ika Nur. (2020). Faktor-Faktor Yang Berhubungan Dengan Kejadian Demam Tifoid Di Rsud Lanto Dg Pasewang Jeneponto. Journal Adpertisi Vol. 1 No. 1.

Diana Maximiliany Sun, Desi Indria Rini, Rr. Listyawati Nurina.( 2019). Uji Aktivitas Antibakteri Larutan Madu Hutan Terhadap Pertumbuhan Escherichia coli Secara In Vitro. Cendana Medical Journal Volume 16, Nomor 1.

Elsi Wineri, Roslaili Rasyid, Yustni Alioes. (2014). Perbandingan Daya Hambat Madu Alami dengan Madu Kemasan secara In Vitro terhadap Streptococcus beta hemoliticus Group A sebagai Penyebab Faringitis. Jurnal Kesehatan Andalas 3(3).

Hapsoro Muhamad Arif Tri, Wicaksono Arif, Wibowo Muhamad Agus. (2018). Uji Aktivitas Antibakteri Ekstrak Metanol Daun Soma (Ploiarium alternifolium Melchior) terhadap Salmonella typhi. Jurnal Cerebellum. Volume 4. Nomor 1.

Marsa Akbar, Elmiyati, Ananda Ery. (2020). Hubungan Personal Hygiene dan Sanitasi Lingkungan Terhadap Prevalensi Terjadinya Demam Tifoid di Rumah Sakit Umum Daerah (RSUD) Meuraxa Kota Banda Aceh Tahun 2018. Jurnal Abulyata Vol.2, No. 2.

Purba Yosua Pandapot, Ramadhian M. Ricky, Sutyarso. (2019). Efektivitas Antibakteri Ekstrak Etanol Mentimun (Cucumis sativus L.) terhadap Pertumbuhan Salmonella typhi. Universitas Lampung Vol 8 No. 2.

Putra I Gusti Putu Agus Ferry Sutrisna, Juliantara I K. Putra, Sukmayanti Ni Luh Putu Ari. (2018). Efektivitas Antibakteri Ekstrak Kulit Batang Kemuning (Murraya Paniculata (L) Jack) Terhadap Pertumbuhan Salmonella Typhi Secara Invitro. Jurnal Media Sains 2 (1): 14 - 20 P-ISSN : 2549-7413 E-ISSN : 26203847.

Rahma Asriani Panjaitan, Sri Darmawati, Muhammad Evy Prastiyanto. (2018). Aktivitas Antibakteri Madu Terhadap Bakteri Multi Drug Resistant Salmonella Typhi Dan Methicillin-Resistant Staphylococcus Aureus. Seminar Nasional Edusainstek ISBN : 978-602-5614-35-4.

Ristiansyah Dilla Ulfa, Yenita, Melviana, Annisa. (2018). Uji Efektivitas Antibiotik Ekstrak Daun Cengkeh (Syzygium Aromaticum) Terhadap Pertumbuhan Bakteri Salmonella Typhi Secara In Vitro. Ibnu Sina Biomedika Volume 2, No. 1 .

Susanto A. (2012). Terapi Madu. Penebar Swadaya: Depok.

Tulandi Silvester Maximus. (2019). The Effect Of Storage Temperature On The Quality Of Honey. Jurnal Teknologi Dan Seni Kesehatan Vol. 10 (1). 2019 : 59 - 71.

Ulum Bahrul, Khanifah Farach. (2017). Uji Daya Hambat Ekstrak Buah Pare (Momordica Charantia) Terhadap Pertumbuhan Bakteri Salmonella Typhi Dengan Metode Difusi. Jurnal Insan Cendekia Volume 5 No.1. 